MINERALOGIA, 39, No. 3-4: 115-119 (2008)

DOI: $10.2478 / v 10002-008-0009-1$

www.Mineralogia.pl

MineRALOGICAL SOCIETY OF POLAND

POLSKIE TOWARZYSTWO MINERALOGICZNE

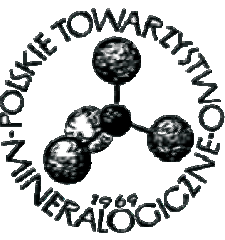

Review

\title{
Fossil fuels, ore and industrial minerals
}

by Dill, H.G., Sachsenhofer, R.F., Grecula, P., Sasvári, T., Palinkaš, L.A., Borojević-Soštarić S., Strmić-Palinkaš S., Prochaska, W., Garuti, G., Zaccarini, F., Arbouille, D., and Schulz H.-M. (2008). In: T. McCann (Ed.), Geology of Central Europe, Geological Society of London, Special Publication, London, 1341-1449 (Fig. 1)

\section{Review by}

Zbigniew SAWLOWICZ1

\footnotetext{
${ }^{1}$ Institute of Geological Sciences, Jagiellonian University, ul. Oleandry 2a, 30-063 Kraków, Poland; e-mail: zbigniew.sawlowicz@uj.edu.pl
}

Received: March 05, 2009

Accepted: March 10, 2009

The recent book on geology of Central Europe summarizes the current knowledge about our part of Europe and for sure it is worth to be red carefully. The extensive chapter on economic geology is an example how to comprise a large volume of information on one hundred pages and to supplement them with the map on CD-ROM. The publication lists majority of the European deposits (especially valuable are old deposits not easy to find in the post-library age of the internet) and covers a large spectrum from economic to genetic. The chapter is divided into several sections: (1) strata-bound deposits (Fig. 2); (2) thrust-bound metamorphogenic and/or fold-related deposits; (3) deposits controlled by collision-related granitic activity; (4) unconformity-related fault-bound hypogene and supergene; (5) deposits controlled by extension-related igneous activity along deep-seated fault zones; and (6) petroleum deposits (Fig. 3). In summary and conclusions the authors discuss sources and processes leading to the formation of the described deposits. A bit misleading is a title of the book which contains the discussed chapter. There are many deposits described here that occur outside of what we think is the Central Europe (e.g. in eastern France), although geologically the selection is justified. 
Fore sure, the publication can be used by many interested in the problem, both students and researchers. It can also be a good addition to the textbooks on mineral deposits, especially that the figures are simplified in good sense and clear. Extensive lists of the deposits, both old and still in use, and the references are of their own values. The biggest problem I had when reading was a lack of clear distinction between small and insignificant deposits and those that sometimes have an attribute of "giant". As in such a large product, some small problems and mistakes can be found there, fortunately they do not have an impact on the overall very positive reader's impression.

I would like to raise one point here, regarding the list of authors. I can imagine it would be easier for the authors and more useful for the readers to describe the deposits by local national researchers, although sometimes they have a tendency to add too many not necessarily needed details. Unfortunately, the practice does not always follows the theory. As Harald Dill, who described some of the non-German deposits, noted "some colleagues were very enthusiastic at the beginning but later on this enthusiasm melted swiftly away like ice in the sun". I do hope some of us will be more conscious and responsible next time, with the benefit to the readers.

I am sure the publication will meet a broad and positive reaction everywhere (not only in Central Europe) and thereby cross-border links will become more comfortable for future cooperation. 


\title{
21 Fossil fuels, ore and industrial minerals
}

\author{
HARALD G. DILL, REINHARD F. SACHSENHOFER \\ (co-ordinators), PAVOL GRECULA, TIBOR SASVÁRI, \\ LADISLAV A. PALINKAŠ, SIBILA BOROJEVIĆ-ŠOŠTARIĆ, \\ SABINA STRMIĆ-PALINKAŠ, WALTER PROCHASKA, \\ GIORGIO GARUTI, FEDERICA ZACCARINI, DIDIER \\ ARBOUILLE \& HANS-MARTIN SCHULZ
}

The mining of metallic and non-metallic commodities in Central Europe has a history of more than 2000 years. Today mainly non-metallic commodities, fossil fuels and construction raw materials play a vital role for the people living in Central Europe. Construction raw materials, albeit the most significant raw material, are not considered further here; for details refer to thematic maps issued by local geological surveys and comprehensive studies such as the textbook by Prentice (1990).

Even if many deposits in Central Europe, especially metallic deposits, are no longer extensive by world standards, the huge number and variety of deposits in Central Europe is unique and allows the student of metallogenesis to reconstruct the geological history of Central Europe from the Late Precambrian to the Recent in a way best described as 'minerostratigraphy'.

The term 'deposit' is used in this review for sites which were either mined in the twentieth century or are still being operated. A few sites that underwent exploration or trial mining have also been included in order to clarify certain concentration processes They are mentioned explicitly in the text to avoid confusion with real deposits. Tonnage and grade are reported in the text only for the most important deposits. Production data for the year 2005 are listed in Table 21.1 for the countries under consideration. Reserves and production data of hydrocarbons in Central European basins are given in Table 21.2.

In the present study, Central Europe covers the Variscan core zones in the extra-Alpine part of Central Europe stretching from eastern France (Massif Central) into Poland where the contact between the Variscan Orogen and the Baltic Shield is concealed by a thick pile of platform sediments. In a north-south direction, Central Europe stretches from central Denmark to the southern boundary of the Po Plain in Italy, making the entire Variscan Foreland Basin, the Alpine Mountain Range, the Western Carpathians and the North Dinarides part of the study area.

An outline of the geological and geographical settings is shown in Figure 21.1. The precise geographical position of mineral sites, wells of special interest, hydrocarbon provinces, oil shale deposits and coal fields may be deduced from Tables 21.3 to 21.11 and the map 'Mineral and energy resources of Central Europe', at a scale 1:2500000 (see CD inside back cover).

Many deposits were mined for different commodities during different time periods. In the text the various types of mineralization of each deposit are described to provide a complete picture of the concentration process through time. In the map (see CD inside back cover), however, each deposit is attributed to that group of commodities for which it was operated for the longest time or for which it is currently mined.

The history of the accumulation of ores, industrial minerals and fossil fuels in Central Europe can be subdivided into two principal phases: the first spans the time period from the Late Proterozoic to the Late Palaeozoic, and the second the epoch from the Late Palaeozoic to the Cenozoic. The first phase is considered as the Variscan cycle, although it includes some deposits of older orogenies, the second is representative of the Alpine cycle. Both cycles overlap slightly. The Variscan metallogenetic cycle fades out with collision-related deposits and the collapse of the Variscan craton during the Late Palaeozoic, while the Alpine cycle commences with coeval intracontinental riftrelated deposits. Those Late Palaeozoic deposits with a great affinity to compressional tectonics are grouped under the heading of the Variscan cycle, whereas those largely related to extensional regimes belong to the Alpine cycle.

There are marked structural and geomorphological differences between the Alpine mountain belt in the southern part of Central Europe and its extra-Alpine northern part. In terms of metallogenesis these differences are minor (see also Froitzheim et al. 2008; Reicherter et al. 2008). Indeed, deposits of Variscan age form an integral part of the metallogenic evolution of the Alpine belt. Furthermore, deposits of Alpine age are found also in the Variscan basement of the extra-Alpine part of Central Europe (Petrascheck 1963; Bernard et al. 1976; Baumann 1979; Pouba \& Ilavský 1986; Walther 1982; Jaffé 1986; Dill 1989; Walther \& Dill 1995).

Metallogenesis in Central Europe has been studied by many researchers, particularly for the great variety of epigenetic deposits, which made the area a textbook example of vein-type ore mineralization (see Schneiderhöhn 1962, and references therein). In the early $1970 \mathrm{~s}$, a tremendous change in the conception of ore formation occurred. Many deposits, notably in the Alpine region, that were formerly interpreted as epigenetic, were re-interpreted as strata-bound and time-bound (Tufar 1972; Maucher 1974).

The classification of mineral and energy resources may be performed in different ways. The traditional classification scheme is based on mineral commodities, metal groups or mineral associations. This approach is suitable for stand-alone mineral resource maps, for papers satisfying the special demands of

Fig. 1. Front page 


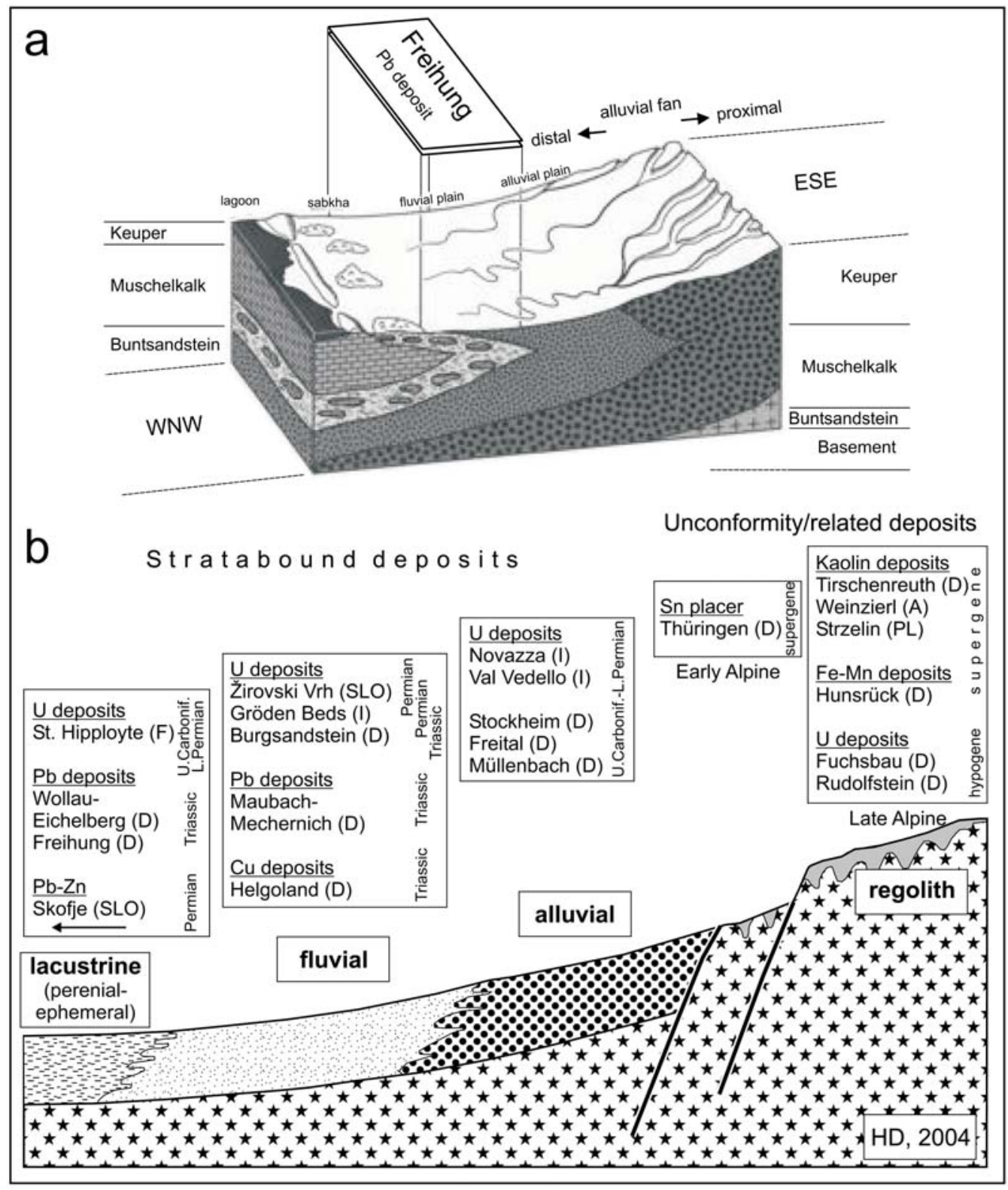

Fig. 2. Dill et al., Fig. 11; exemple of the stratabound deposits 

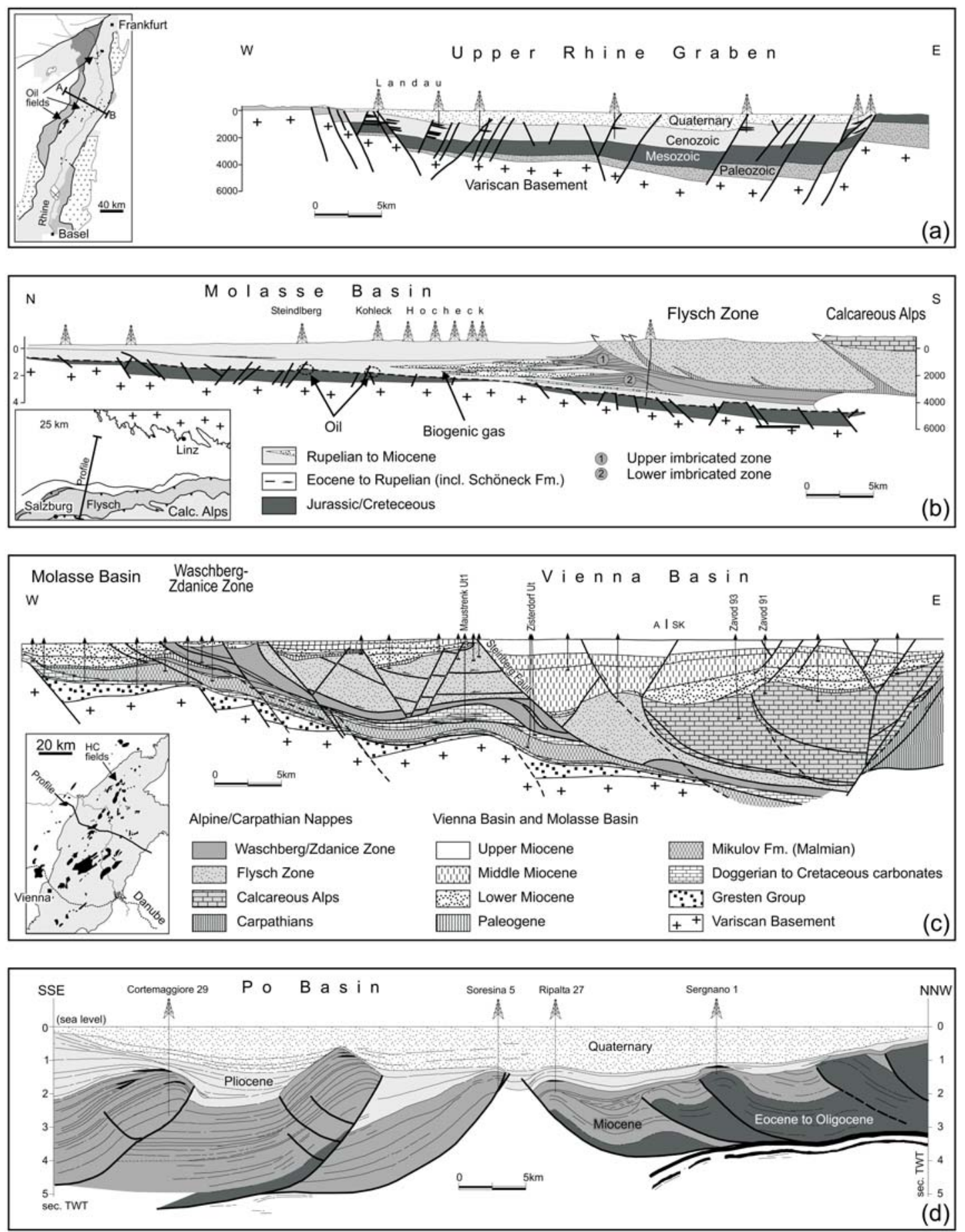

Fig. 3. Dill et al., Fig. 26; exemple of the petroleum deposits 
